FEMP PAPER - 2377

\title{
STATUS REPORT: FERNALD SITE REMEDIATION
}

by:

Jack R. Craig, Jr. Department of Energy, Fernald Area Office

James A. Saric, U.S. Environmental Protection Agency

Thomas Schneider, Ohio Environmental Protection Agency

Michael K. Yates, FERMCO*

January 30, 1995

\author{
FERMCO* \\ Fernald Environmental Management Project \\ P.O. Box 398704 \\ Cincinnati, OH $45239-8704$
}

For Presentation at the

WM'95 Conference

February 26 - March 3, 1995

Tucson, AZ

*Fernald Environmental Restoration Management Corporation with the U. S. Department of Energy under Contract No. DE-AC05-92OR21972

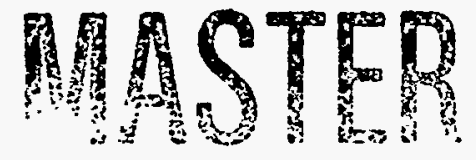




\section{DISCLAIMER}

Portions of this document may be illegible in electronic image products. Images are produced from the best available original document. 


\section{DISCLAIMER}

This report was prepared as an account of work sponsored by an agency of the United States Government. Neither the United States Government nor any agency thereof, nor any of their employees, make any warranty, express or implied, or assumes any legal liability or responsibility for the accuracy, completeness, or usefulness of any information, apparatus, product, or process disclosed, or represents that its use would not infringe privately owned rights. Reference herein to any specific commercial product, process, or service by trade name, trademark, manufacturer, or otherwise does not necessarily constitute or imply its endorsement, recommendation, or favoring by the United States Government or any agency thereof. The views and opinions of authors expressed herein do not necessarily state or reflect those of the United States Government or any agency thereof. 


\section{STATUS REPORT: FERNALD SITE REMEDIATION}

Jack R. Craig, Jr. Department of Energy, Fernald Area Office

James A. Saric, U.S. Environmental Protection Agency

Thomas Schneider, Ohio Environmental Protection Agency

Michael K. Yates, FERMCO

\section{ABSTRACT}

The Fernald site is rapidly transitioning from an Remedial Investigation/ Feasibility Study (RI/FS) site to one where design and construction of the remedies dominates. Fernald is one of the first sites in the Department of Energy (DOE) complex to accomplish this task and real physical progress is being made in moving the five operable units through the CERCLA process. Two of the required Records of Decision (ROD) are in hand and all five operable units will have received their RODs (IROD for OU3) by the end of 1995. Pre-design investigations, design work or construction are now in progress on the operable units.

The lessons learned from the work done to date include implementing innovations in the RI and FS process as well as effective use of Removal Actions to begin the actual site remediation. Also, forging close working relationships with the Federal and State Regulators, citizens action groups and the Fernald Citizens Task Force has helped move the program forward. The Fernald successes have been achieved by close coordination and cooperation among all groups working on the projects and by application of innovative technologies within the decision making process.

\section{INTRODUCTION}

The Fernald site is located approximately 20 miles northwest of Cincinnati and has been managed by Fernald Environmental Restoration Management Corporation (FERMCO) since December, 1992. For more than 37 years, the facility manufactured uranium metal products for use at other DOE sites to satisfy Defense Program demands. Production operations were suspended on July 10, 1989 due to a sharp reduction in the demand for uranium metal products by user sites and continuing problems in achieving full regulatory compliance. Following necessary Congressional notifications, the facility was formally shut down on June 19, 1991 when its mission became environmental restoration.

The primary law regulating cleanup of the Fernald site is the Comprehensive Environmental Response, Compensation, and Liability Act (CERCLA) as amended by the Superfund Amendments and Reauthorization Act (SARA) in 1986. Another major regulation, the Resource Conservation and Recovery Act of 1976 (RCRA), governs the generation, transportation, treatment, and disposal of the hazardous waste at the site. A Consent Decree was signed by the State of Ohio and the DOE in December, 1988, establishing milestones to bring the FEMP into full compliance with RCRA and other regulatory requirements. Amendments establishing additional milestones regarding the management of hazardous waste were later proposed to the Consent Decree, and in January 1993, the amendments were approved, resulting in the Consent Decree and its Stipulated Amendments (SACD). 
In July 1990, the United States Environmental Protection Agency (USEPA) and the DOE entered into a Consent Agreement establishing milestone schedules for the completion of necessary studies to support the CERCLA clean-up process. The agreement established schedules for implementing near term clean-up actions (Removal Actions) while final clean-up solutions were being evaluated and selected. In September 1991, the DOE and USEPA jointly signed the Amended Consent Agreement establishing revised milestones for the completion of the required studies and identifying a series of additional near-term actions for implementation by the DOE.

Here are some background notes of significance:

\section{Production}

- Production initiated in 1952

- Operations placed on hot standby in July, 1989

- Formal plant closing - August, 1990

- Total Uranium Production (1952 to 1989) - 462 million pounds U delivered product

- Average Waste Generation Rate - 2.2 lbs waste per pound U product

- Total Waste Product ( 37 year product history) - 1 billion pounds

- Maximum Annual U Production - 10 metric tons (1960)

\section{Environmental Issues}

- Plant designed to spray calcine raffinate, with pit usage exclusive to lower volume off specification material

- 1958 economic confrontation with Weldon Spring led to decision to abandon spray calcining process and build raffinate pits

- All process residues sent to pits/silos from startup to August, 1984

- August, 1984 began drumming all raffinates

- 80,000 drum waste inventory created by end of 1987

- Pits ceased to be used in April, 1987

- Plant estimates 400,000 lbs U discharged to atmosphere over 37 year production history

The Fernald site is broken down into five operable units. The following paragraphs discuss the scope and current status of each, along with a description of the remedy and discussion of some of the innovations employed on each and the lessons learned. Figure 1 provides an overall schedule for the five OUs.

\section{INSERT FIGURE 1 HERE}

\section{OPERABLE UNIT 1 - WASTE PITS}

\section{Scope}

Waste Pits 1 through 6

Clearwell

Burnpit 
Berms, Liners and Soils Within the OU Boundary

$\underline{\text { Status }}$

RI and FS/PP Reports submitted and approved

Final ROD submitted January 26, 1995

ROD signature expected February 1995

Pre-Design investigation in process

\section{Description of Remedy}

The Proposed Plan for the remediation of OU1 involves the excavation of an estimated 710,000 cubic yards of waste materials from six waste pits and two ancillary contaminated areas, the drying of this waste to meet waste acceptance criteria and its disposal in a permitted commercial disposal facility.

\section{Highlights}

In order to facilitate obtaining the Record of Decision for OU1, a successful strategy for informing the stakeholders of the Proposed Plan for Operable Unit 1 was employed. One of the greatest concerns to the public is the safety and integrity of transshipment by rail of waste materials along the spur connecting the FEMP with the main rail line to the west. In anticipation of the issues that the stakeholders would raise at the CERCLA public meeting scheduled for August 23, 1994 where formal comments from the public would be received on the Proposed Plan, OU1 held a series of public meetings prior to the official meeting to assure a thorough airing of the issues. A Rail Transportation Workshop was held on August 9, 1994 where a complete disclosure of DOE's plans for rail transport was laid out. A followup availability Session was held a week later on August 16, 1994 with CSX, the rail carrier along the spur line and the carrier for the waste freight from the FEMP to East St. Louis, Illinois. DOE's unit train concept and sealed gondola plans, Emergency Response activities, potential use of adjacent rail facilities were described and discussed with the objective of determining the public's overall reaction to the DOE Transportation plans. These reactions were then addressed and incorporated into the presentations which were made to the public at the formal public meeting held on August 23.

Ohio EPA's Office of Federal Facilities Oversight held an availability session with members of the public during the public comment period and prior to the public hearing for the OU1 Proposed Plan. Availability sessions are held by Ohio EPA during the public comment period for each operable unit's Proposed Plan. The meetings provide an informal atmosphere for the citizens to ask questions and share concerns one on one with the agency. In addition, Ohio EPA is able to inform the public and address some issues that would otherwise have to arise through the formal public comment process.

As a result the public meeting was a very smooth, non-confrontational exchange of ideas about which USEPA's remedial project manager stated that "this was the best public meeting that he had attended." 
It is estimated that $\$ 300-400 \mathrm{M}$ could be saved if OU1 were allowed to ship waste in bulk to a commercial disposal facility such as the Envirocare facility currently in operation at Clive, Utah instead of sending the waste materials to the Nevada Test Site (NTS). These estimated savings derive both from the packaging requirements associated with NTS disposal and from the intermodal transfer required to dispose at NTS since NTS does not currently have any direct rail service to its disposal areas. Working closely with DOE HQ, OU1 sought and successfully obtained an exemption from the portion of the DOE order 5820.2A which requires the DOE to dispose of low level radioactive waste at a DOE facility. The exemption, which is specific to OU1 at Fernald, allows OU1 to dispose of Low Level Waste materials at a permitted commercial disposal facility.

In order to optimize the excavation of the waste, a program entitled the Dewatering, Excavation Evaluation Program (DEEP) project was launched in 1994. DEEP consists of a 4 phase project; geotechnical testing, wet excavation, dewatering, and dry excavation for waste pits 1,2 , and 3 . Waste pits 1,2 , and 3 were selected because these pits represent over $80 \%$ of the total waste OU1 plans to dry excavate during remediation.

Geotechnical testing will be utilized to evaluate the characteristics and geotechnical properties of the waste before, during, and after dewatering tests have been conducted. Wet excavations consisting of pre-dewatering back hoe excavations and waste reslurrying and pump tests will be performed after initial geotechnical testing. The feasibility of dewatering will be established by comparatively testing alternative well configuration and well types and through the testing of electro-osmosis and vacuum assist enhancements to determine the optimal method to employ during final remediation. Dry excavations, to include dry trench excavation and ramp excavation, will be performed to determine the efficiency of the dewatering techniques, amenability of the waste to excavation and handling, and the ability of the waste to support heavy equipment. To date, the initial geotechnical testing has been completed in the waste pits.

Wet excavations are scheduled to begin in mid-January, followed by dewatering, and dry excavation.

\section{OPERABLE UNIT 2 - OTHER WASTE UNITS}

\section{Scope}

Fly Ash Piles

Lime Sludge Ponds

Solid Waste Landfill

Other South Field Disposal Areas

Berms, Liners and Soils Within the OU Boundary

Status

RI and FS/PP Reports submitted and approved Draft ROD submittal scheduled February 1995 ROD signature expected June 1995

Pre-Design investigations in process 


\section{Description of Remedy}

Excavation of materials and disposal in an on-site disposal cell. Shipment of any hot spots offsite.

Figure 2 shows the preliminary size and location of the on-site cell.

\section{INSERT FIGURE 2 HERE}

\section{Highlights}

\section{- Three Dimensional Modeling}

Throughout the Operable Unit 2 remedial investigation process, soil and groundwater sampling results were fed into a modeling process that accounted for spatial variations in the data and created an estimate in 3D of the extent of contamination. The resulting graphics provided images that were easy to understand and easy to remember. Those images simplified interaction between the DOE and the EPAs and provided an important tool for informing the public about the operable unit.

- Reduced Time Frame \& Cost for Laboratory Services

The new FEMP program for preapproval of chemical analysis laboratories resulted in shorter procurement periods and reduced overall costs during recent Operable Unit 2 groundwater monitoring and the second phase of the disposal facility predesign investigation.

\section{- Cone Penetrometer Testing}

Cone penetrometer tests (CPTs) are being used in the proposed disposal facility predesign investigation. The objective of this preliminary work is to better define the lithology in the potential facility location. The CPTs have proven to be five to ten times faster than routine drilling and to have associated cost savings. While CPTs do not provide samples for ex situ testing, they do provide full classification over the depth of the borehole.

The information learned from the CPTs also allows better placement of future wells and borings.

- Meetings for Citizen Involvement on the Proposed Disposal Facility

DOE organized three opportunities for the public to discuss the proposed on-site disposal facility. Two public workshops were held, on June 28 and October 25, 1994, to discuss the Operable Unit 2 Feasibility Study/Proposed Plan and details of the preferred remedial alternative. A public meeting took place on November 8, 1994. During this meeting, DOE answered questions and accepted formal public comments on the Operable Unit 2 Proposed Plan and preferred remedial alternative. In addition to the DOE workshops and meeting, OEPA sponsored two availability sessions, in September and November, to discuss the 
Operable Unit 2 Proposed Plan and preferred remedial alternative. DOE also made presentations to smaller groups of local elected officials at their request. A priority has been placed on public outreach for this remedial action because of the sensitivity and strong public opinions associated with leaving waste on-site in an engineered disposal facility. Important perspective and useful input on this set of issues resulted from deliberations by the Fernald Citizens' Task Force. Indeed, Task Force input was instrumental in determination of the proposed remedy for OU2.

\section{OPERABLE UNIT 3 - FORMER PRODUCTION AREA}

\section{Scope}

All Man-Made Structures and Facilities at the Fernald Site, Above and Below Ground.

\section{$\underline{\text { Status }}$}

Interim ROD issued July 1994, which allows D\&D of all OU3 facilities

A D\&D contract has been placed to take down the Plant 4 complex. RI/FS/PP Report submittal scheduled to EPA September 11, 1995.

Draft Final ROD (disposition of waste material) submittal scheduled July 25, 1996.

\section{Description of Remedy}

Dismantlement of structures, excavation of materials and disposal in an on-site storage cell. Some items and material may be disposed offsite. Considerable emphasis on recycling.

\section{Highlights}

The Record of Decision for the Interim Remedial Action, signed by EPA on July 22, 1994, represents the first Operable Unit Record of Decision for the Fernald Site. This landmark decision allows remediation of the site buildings and structures to proceed, resulting in significant cost savings and schedule acceleration.

Plant 7 represents the first Fernald Facility to undergo the D\&D process. As Fernald's tallest structure, the Plant 7 takedown became a symbolic gateway to future work at the site. (See Figure 3) The task was difficult and frustrating at times, and the successful takedown was the result of diligent planning, hard work, and perseverance by all involved. The project, in spite of the building's resistance to our planned efforts, was completed significantly ahead of schedule and below cost.

The CRU3 RI/FS Field Investigations Program initiated the field sampling activity in late September 1993 and completed it on August 4, 1994. The program was completed 6 weeks ahead of schedule and under budget. During this time 1000 construction samples were collected. The samples were of excellent quality, resulting in a zero resample rate. Also, an impressive record of zero down time in the field and no lost time injuries are testimony to the good planning and enthusiasm of the program's personnel. 


\section{Other significant highlights .}

- Plant 1 Ore Silos - completed demolition

- Fire training facility - completed demolition

- Plant $1 \mathrm{Pad}$ - expanded/upgraded capability to stage and process remediation waste streams.

- Awarded contract to recycle 700 tons of structural steel.

- Completed demolition of Plant 7.

- Established a prioritization and sequencing schedule and associated cost estimate for decommissioning of all Fernald facilities consistent with site wide remediation goals.

OPERABLE UNIT 4 - SILOS

Scope

Silos 1 and 2 (K-65 Silos)

Silo 3 - Metal Oxides

Silo 4 - Empty

Decant Sump System

Soils and any Buried Concrete

Berm Surrounding Silos 1 and 2

Perched Water (encountered During Remediation)

Status

$\mathrm{RI}$ and FS/PP Reports submitted and approved

ROD signed December 1994

Pilot Plant under construction, glass making to begin in July 1995, with radioactive glass scheduled for late 1995.

\section{Description of Remedy}

Remove silo contents by hydraulic excavation, vitrify the waste, ship to Nevada Test Site for final burial.

\section{Highlights}

Operable Unit 4 was the first operable unit to incorporate NEPA requirements into the CERCLA process at Fernald. This had a dramatic effect on the time and cost for responding to the requirements of each law, taking some extra time to begin with, but reducing the overall requirements by elimination of duplicate efforts. This was done through a Notice of Intent which integrated the process and documentation packages into a Feasibility Study/Proposed PlanEnvironmental Impact Statement (FS/PP-EIS). The first final ROD for the Fernald site was also OU4's and was signed on December 7, 1994. This started the clock under the CERCLA process for remediation to commence within 15 months.

Several technical innovations are part of the OU4 project and revolve around the need to handle 
the silo material with care. The K65 silos are the largest radon concentration source in the United States (and maybe the world). Gas headspace in silo 2 is approximately 3 million pico curies per liter and the interstitial gas space in the solids may approach 40 million pico curies per liter. To deal with this concentration, the K65 material will be removed with a hydraulic mining pump which will contain the radon to a large extent as a soluble gas in the water and the vitrification plant itself will use activated carbon for removal of radon from the process gas streams. A small robotic device is planned for final cleanout of the heels in the tank so that the last traces of the spent ore can be removed before the silos are dismantled.

New analytical techniques are being tried and some are being custom designed to deal with the large range of radon concentrations that will be seen in the pilot plant. Concentrations are expected to range from environmental levels of around 1 to $4 \mathrm{PCi} / \mathrm{L}$ to over $60,000 \mathrm{PCi} / \mathrm{L}$ in the process itself. Advances in scintillation counting and in personnel monitors are being tracked as part of the project.

A new approach to high temperature vitrification furnace design is, incorporated into the vitrifier for this facility because of the very high (approximately 1400 degrees C) temperatures expected to be needed for portions of the waste stabilization. The vitrification process will reduce the radon emanation rate by a factor of approximately 500,000 versus the silo material in its present form. The tighter glass structure of the vitrified product will retain the radon within the matrix. so that it decays in place to a much larger extent that is presently the case in the powder in the silos.

The headspace in the $\mathrm{K} 65$ silos was very high in radon concentration (over 20 million picocuries per liter) and contributing to high levels of radon near the fenceline of the facility due to natural diurnal aspiration of the silos. A removal action was initiated to reduce the headspace concentration and thus reduce the overall release rate.

The approach selected was to cover the silo material with a cap of bentonite clay which acts as a barrier to diffusion of the radon from the underlying silo material. The radon was retarded in its ability to reach the headspace and the natural decay process of 3.8 days half life captured more of the radon progeny in the clay and silo material. The radon headspace concentration was reduced by approximately a factor of 10 to just over 2 million picocuries per liter so that the radon flux from the silos was reduced.

\section{OPERABLE UNIT 5 - ENVIRONMENTAL MEDIA}

\section{Scope}

Groundwater (Great Miami Aquifer)

Groundwater (Perched Water)

Surface Water

Soils (Not Associated with OU1 - OU4)

Sediment

Flora and Fauna 
$\underline{\text { Status }}$

$\mathrm{RI}$ and FS/PP Reports submitted

ROD submittal scheduled October 1995

ROD approval expected November 1995

\section{Description of Remedy}

Pump and treat ground water, place soils in cell where WAC is acceptable, ship hot spots offsite.

\section{Highlights}

The high degree of success of the OU5 RI/FS effort is directly attributable to the evolution of successful communication between DOE and the regulatory agencies. This has been developed through frequent meetings and discussions with the regulatory agencies during the preparation and implementation of work plans for field sampling programs, fate and transport model improvement process, and the development of procedures and protocols for risk assessment. Although initial efforts were tentative in the late 1980s, by 1993 a high level of communication had been achieved through technical information exchange meetings, informal data presentations and discussions between technical staffs which continue today. As a result, the reports and work plans submitted to the agencies by OU 5 have been accepted with a minimum of revision and comment by the agencies, because the work performed was consistent with agency expectations.

The second principal factor in the success of OU5 has been the use of a phased approach to conducting the remedial investigation and developing models for fate and transport in groundwater as well as the risk assessments. The 1988 RI/FS Work Plan set the goals of the investigation and the initial steps to be taken in the RI/FS. During the investigation, frequent review of the data as it was gathered resulted in work plan addenda that were focused on specific, narrowing, data needs. This approach ensured the best scientific and engineering practices were effectively applied to the investigation using the available resources. These reviews culminated in the 1993 field sampling programs in which remaining data needs were adequately addressed to complete the RI and conduct the FS.

These data reviews also led to the development of significant removal actions such as the South Groundwater Plume Removal Action. Implementation of the removal actions began the transition from RI/FS activities into actual cleanup activities well in advance of the ROD. Implementation of the removal actions has also provided for the phased development and scale up of treatment facilities based on operating experience with the constituents at the FEMP.

The size of the investigation area and the complex interplay of the pathways involving air deposition, surface water infiltration to perched groundwater, surface water transport and infiltration to the Great Miami Aquifer, and infiltration from perched groundwater to the Great Miami Aquifer resulted in the installation of over 1300 borings and 750 monitoring wells. Subsurface soil samples were collected from the borings and groundwater samples were collected from the wells. In addition, samples of surface soil, surface water, and sediment samples were 
collected. These samples were analyzed for one or more parameters from a list of radiological constituents, hazardous substances, and pesticides/PCBs. As a result a database of over $1,000,000$ records of analytical data was organized, verified, and validated for the OU $5 \mathrm{RI}$ and FS. The database includes RI data collected under work plans developed for each of the five operable units and incorporates pre-RI data and FEMP routine environmental monitoring data with appropriate validation qualifiers. Environmental data collected during routine monitoring and $\mathrm{RD} / \mathrm{RA}$ sampling for each operable unit at the FEMP will continue to be incorporated into this database. The database will be an invaluable resource to the development of RD/RAs for OU 5.

Fernald developed a successful ecological risk assessment strategy in conjunction with USEPA in early 1993, and incorporated the site-wide ecological risk assessment into the OU5 RI Report. Risks were evaluated in specified study areas of the FEMP to estimate potential risks to specific ecological receptors (as defined in the approved strategy). The risk assessment strategy was negotiated early with the regulators to facilitate prompt review and approval. These efforts were successful as reflected in the receipt of only minor comments from the USEPA, OEPA and support contractors.

Overall, a 17 volume RI Report, including an attached plate of over 350 maps, was submitted to the EPAs for approval. The document contained over 35,000 pages and represented the anthology of the more than 11 years of investigations of the environmental conditions at the FEMP and surrounding areas. Its approval represents a consensus on the part of all involved organizations that the nature and extent of environmental contamination at the FEMP site has been appropriately defined. Under a rigorous review by the regulatory agencies and their support subcontractors, the RI Report received only relatively minor review comments. The level of comments was reflective of the cooperative spirit that had been fostered between OU5 and the regulators through the use of this highly interactive document planning process.

The progressive data reviews associated with the field investigations program of the RI/FS led to the identification of near-term environmental issues. The identification of these issues facilitated the performance of a series of removal actions focused on attenuating the further migration of contaminants or minimizing the release of contaminants from the facility.

Issues relating to future use of the Fernald Site are mainly addressed in Operable Unit 5, and they incorporate input and recommendations from the Fernald Citizens' Task Force on future use.

\section{Contaminated surface water controls}

- 1986 - Storm water retention basin installed - Controlled the bulk of the contaminated runoff from the production area which was the primary source of contamination to the Great Miami Aquifer

- 1988 - Surface water control of the plant 1 pad - Rerouted contaminated runoff from the pad and periphery to the stormwater retention basin 
- 1992 - Waste pit area runoff control (Removal Action No. 2) - Controlled contaminated runoff from the waste storage area (OU1) and the K-65 silo area (OU4)

- 1993 - Waste pit area containment improvement (Removal Action No. 22) - Involved minimizing the potential for wind and water erosion of contaminated materials by seeding exposed and stressed surfaces in the OU1 study area.

- 1993 - Collect uncontrolled production area runoff (Removal Action No. 16) -Controlled additional contaminated areas around the perimeter of the production area

Groundwater

- 1989 - Contaminated water below FEMP buildings (Removal Action No. 1) - Pumps highly contaminated perched water to reduce the potential for contamination to migrate to the Great Miami Aquifer - Water beneath plants $2 / 3,6,8$, and 9 is being pumped and treated for VOCs and uranium

- South Groundwater Contamination Plume (Removal Action No. 3) - implementation of its five parts is phasing into the OU5 remedy for groundwater contamination. See Figure 4 for a schematic of the South Plume.

Part 1 - provide an alternate water source to an affected industry - completed

Part 2 - install a groundwater recovery well system to extract and pump groundwater back to the FEMP site for monitoring and discharge to the Great Miami River Initiated Pumping August 1993. Also, installed a new HDPE outfall pipeline with fusion welded joints thus addressing the questionable integrity of the existing outfall and providing for future remediation waste water flow capacity.

Part 3 - construct an interim advanced wastewater treatment facility to remove additional uranium from site waste streams to reduce uranium discharges to the Great Miami River - Online since July 1992; treats $300 \mathrm{gpm}$ from storm water retention basins (500 - $700 \mathrm{ppb}$ to $<.1 \mathrm{ppb}$ total uranium) and up to $100 \mathrm{gpm}$ other plant process/ storm water (1000 - $1500 \mathrm{ppb}$ to approximately $10 \mathrm{ppb}$ total uranium)

Part 4 - monitor groundwater more frequently and prevent use of contaminated groundwater - Ongoing, began in 1992

Part 5 - identify the location and extent of any remaining contamination attributable to the FEMP site (i.e., locate the leading edge of the plume exceeding the $20 \mathrm{ppb}$ level) - Complete 1992

\section{South Plume Interim Treatment project}

- Dedicated treatment for $200 \mathrm{gpm}$ South Plume groundwater

- Treats water containing $20-30 \mathrm{ppb}$ uranium to $<.1 \mathrm{ppb}$ uranium 
- Initiated continuous treatment in March 1994

\section{Advanced Wastewater Treatment facility}

- Scheduled to be online January 1995

- Phase I will treat $700 \mathrm{gpm}$ of stormwater from SWRB or groundwater as capacity exists

- Phase II is $400 \mathrm{gpm}$ treatment capacity for existing process waste water, South Plume groundwater, and future remediation waste water from other OUs

- Both Phases will focus on uranium removal

Provision of alternate potable water supplies to homeowners whose private wells were impacted by the South Plume - Supplies bottled drinking water to homeowners whose water supply has been affected by the FEMP (Uranium concentrations $<2.7 \mathrm{ppb}$ ).

Providing funding and technical support to the Hamilton County Department of Public Works to construct a reliable public water supply for residences around the FEMP.

\section{SUMMARY}

Fernald's environmental restoration program is well along the path from site investigation into genuine remediation. Success in this transition has been driven by innovations in regulatory relations; extensive stakeholder involvement; judicious application of technology; and innovative approaches to project management which have improved safety, accelerated schedules, and reduced costs. 


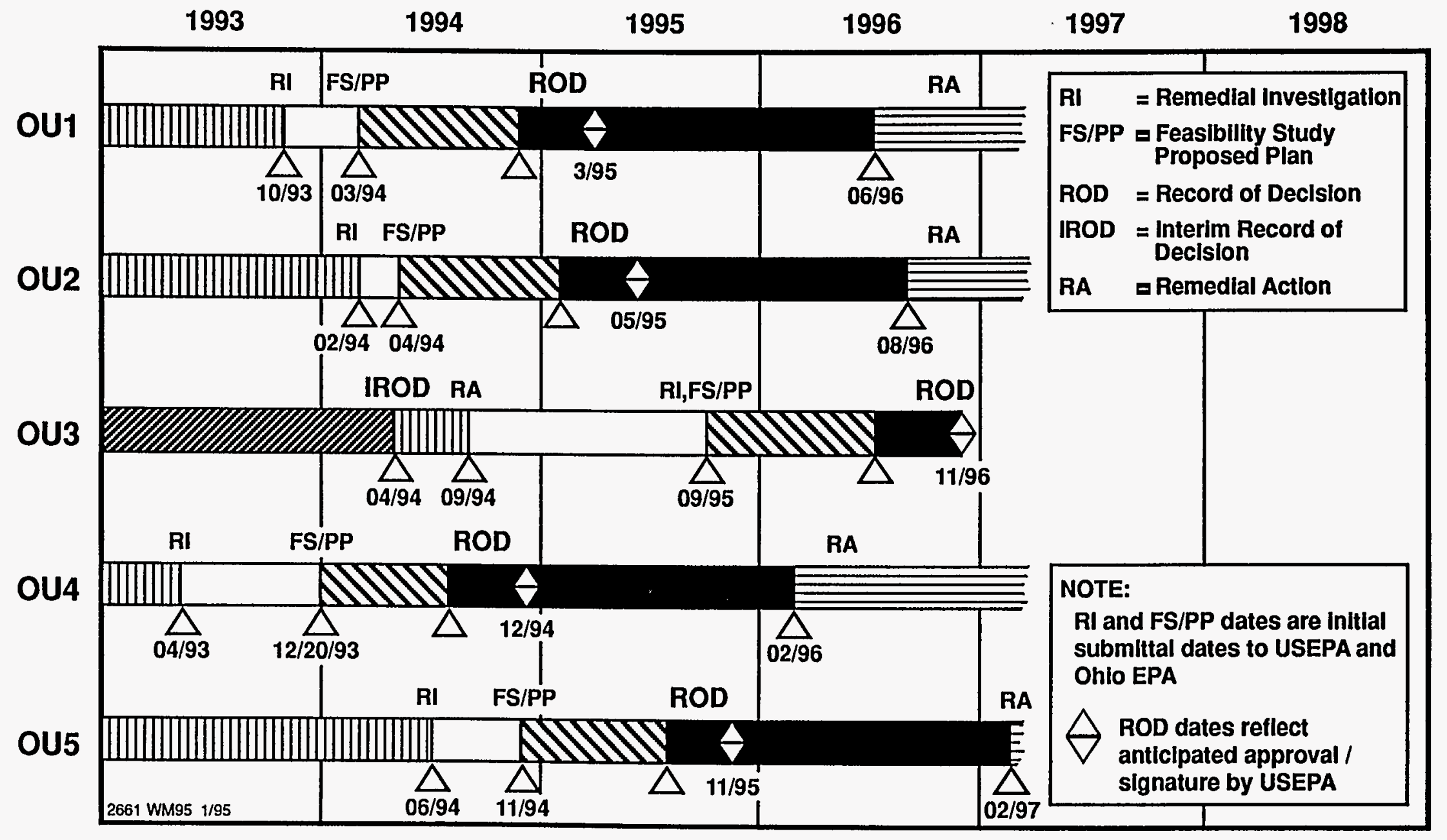

Figure 1. Overall Schedule for Fernald Operable Units 
Fernald Site Boundary

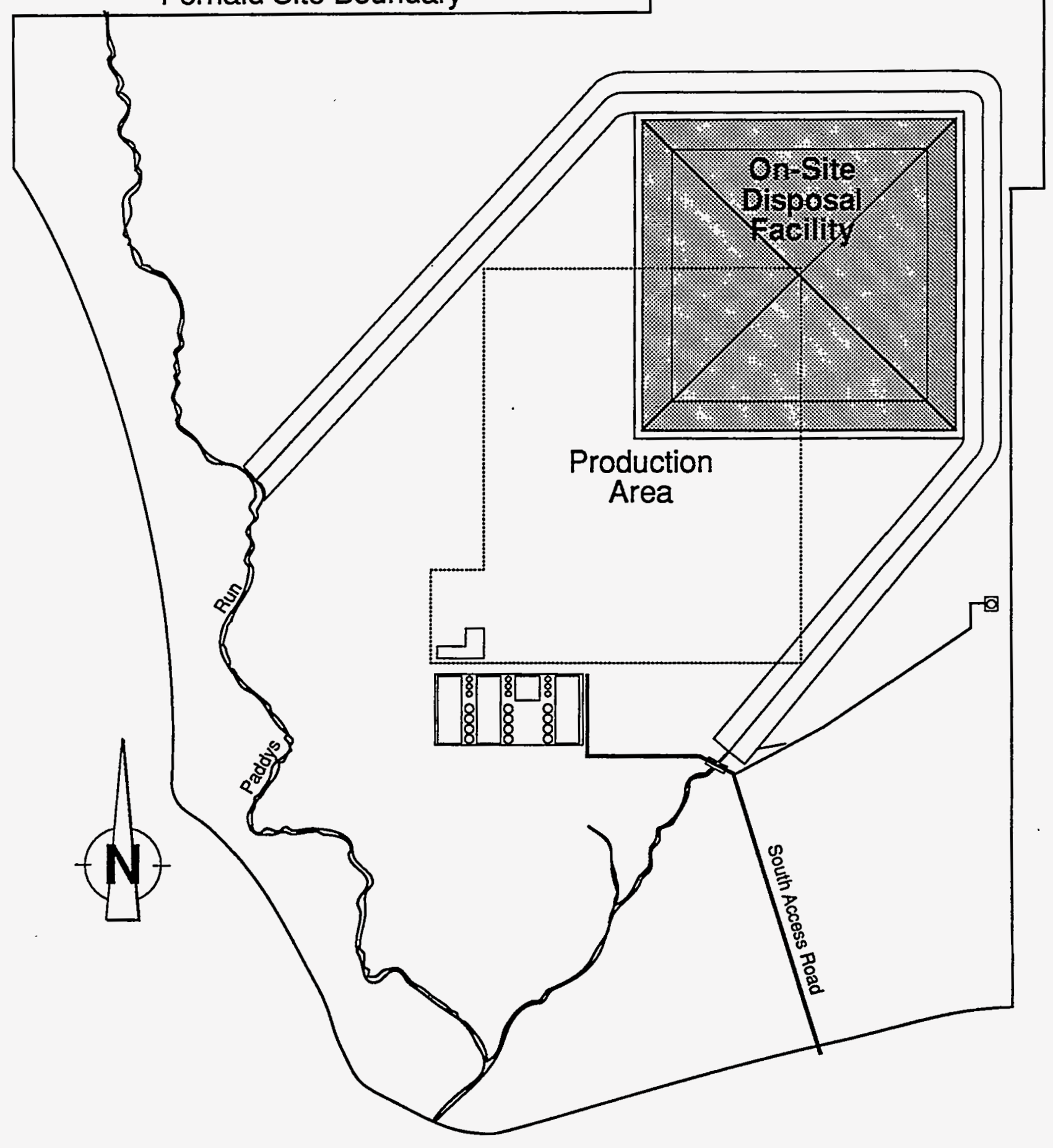

Figure 2. Proposed Location of On-Site Disposal Facility 


\section{Before}

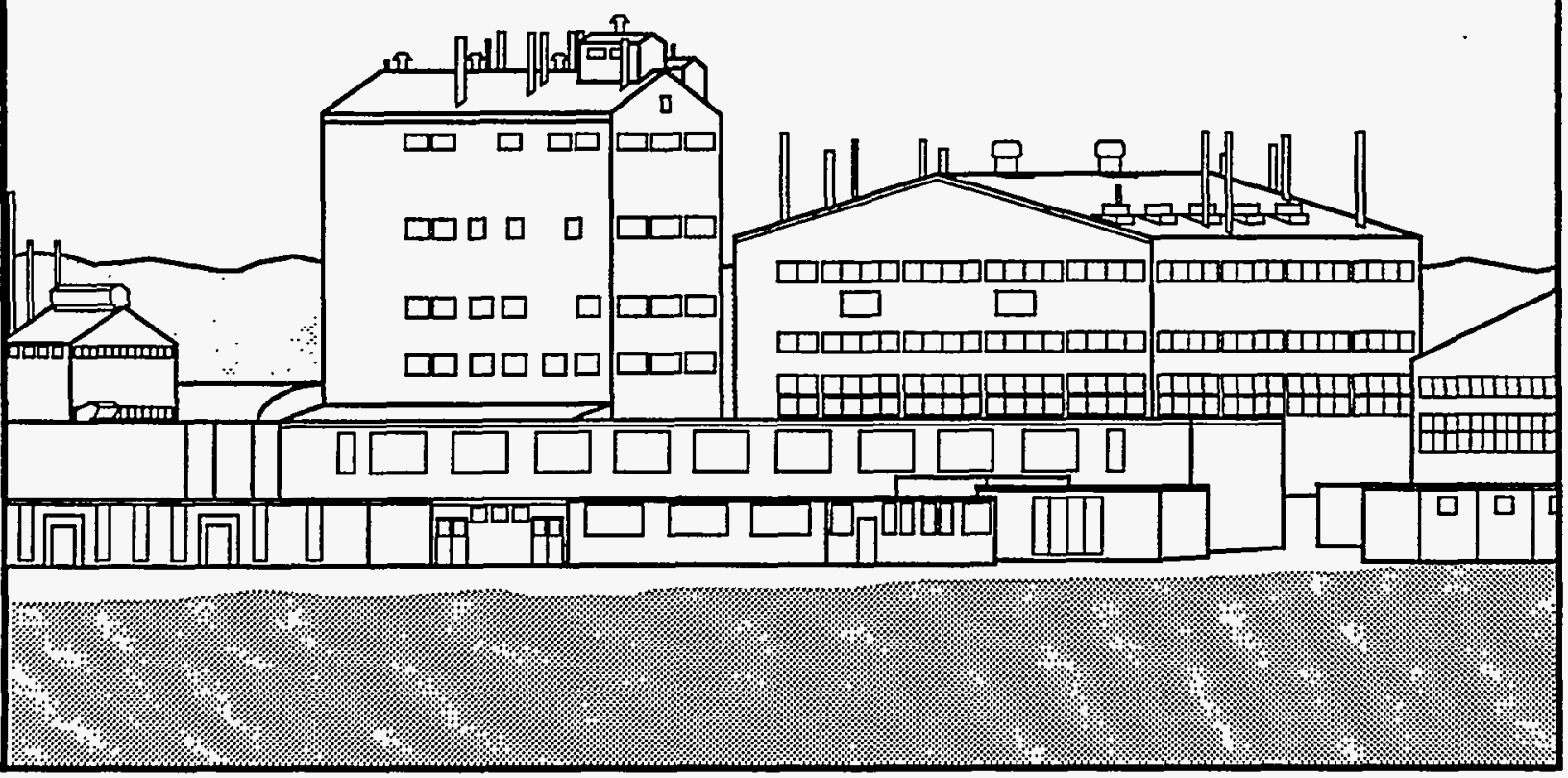

\section{After}

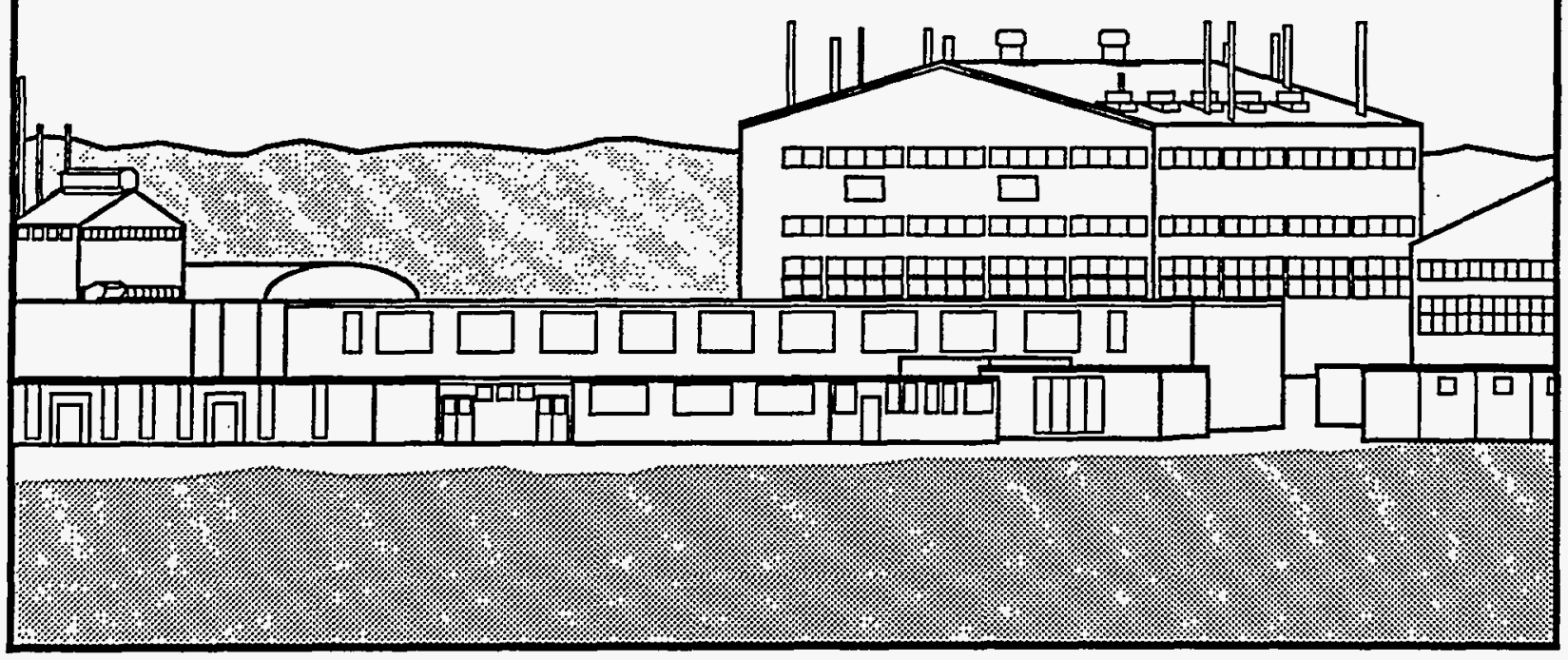

Figure 3. Fernald skyline with and without Plant 7. 


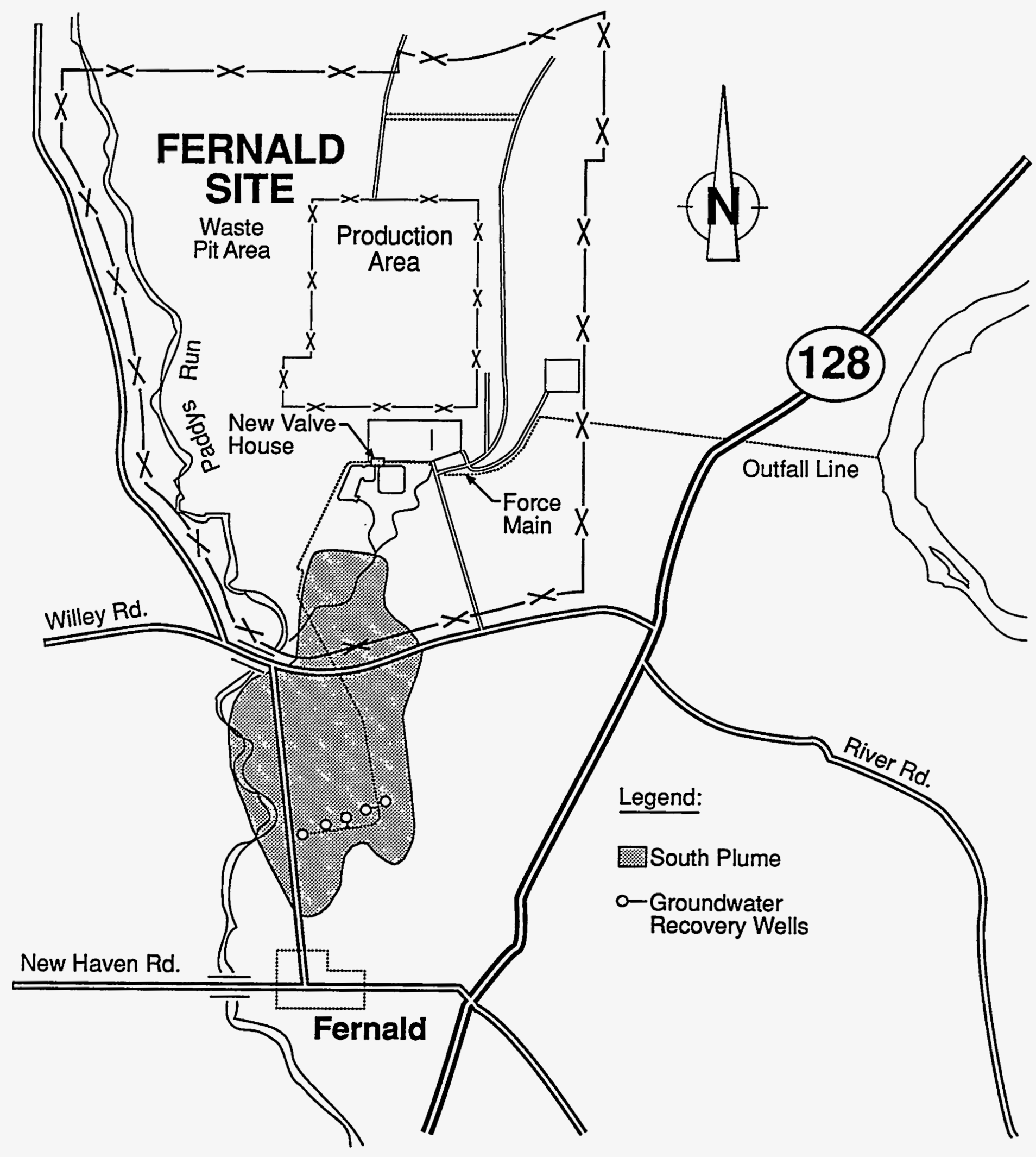

Figure 4. South Plume 